This article was downloaded by: [Radboud Universiteit Nijmegan]

On: 5 January 2009

Access details: Access Details: [subscription number 789289214]

Publisher Routledge

Informa Ltd Registered in England and Wales Registered Number: 1072954 Registered office: Mortimer House, 37-41 Mortimer Street, London W1T 3JH, UK

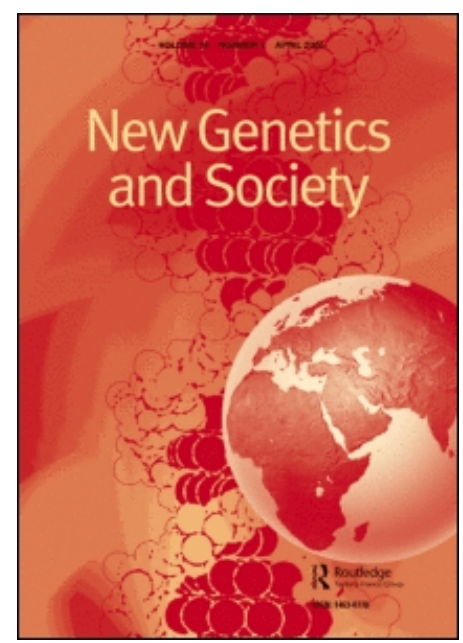

New Genetics and Society

Publication details, including instructions for authors and subscription information:

http://www.informaworld.com/smpp/title content=t713439262

\title{
Understanding the Human Genome Project: a biographical approach
}

Hub Zwart a

${ }^{a}$ Department of Philosophy \& Science Studies, Centre for Society \& Genomics, Faculty of Science, University of Nijmegen, The Netherlands

Online Publication Date: 01 December 2008

To cite this Article Zwart, Hub(2008)'Understanding the Human Genome Project: a biographical approach',New Genetics and Society, $27: 4,353-376$

To link to this Article: DOI: $10.1080 / 14636770802485434$

URL: http://dx.doi.org/10.1080/14636770802485434

\section{PLEASE SCROLL DOWN FOR ARTICLE}

Full terms and conditions of use: http://www.informaworld.com/terms-and-conditions-of-access.pdf

This article may be used for research, teaching and private study purposes. Any substantial or systematic reproduction, re-distribution, re-selling, loan or sub-licensing, systematic supply or distribution in any form to anyone is expressly forbidden.

The publisher does not give any warranty express or implied or make any representation that the contents will be complete or accurate or up to date. The accuracy of any instructions, formulae and drug doses should be independently verified with primary sources. The publisher shall not be liable for any loss, actions, claims, proceedings, demand or costs or damages whatsoever or howsoever caused arising directly or indirectly in connection with or arising out of the use of this material. 


\title{
Understanding the Human Genome Project: a biographical approach
}

\author{
Hub Zwart*
}

Faculty of Science, University of Nijmegen, Department of Philosophy \& Science Studies, Centre for Society \& Genomics, The Netherlands

This article analyzes a number of recently published autobiographies by leading participants in the Human Genome Project (HGP), in order to determine to what extent they may further our understanding of the history, scientific significance and societal impact of this major research endeavor. Notably, I will focus on three publications that fall under this heading, namely The common thread by John Sulston (2002/2003), The language of God (2006) by Francis Collins and A life decoded by Craig Venter (2007). ${ }^{1}$ What may we learn from these autobiographical sources about the dynamics of scientific change? What is their added value in understanding science in general and the HGP in particular? These questions will be elaborated in three directions: on the level of knowledge (epistemology), power (politics) and the Self (ethics). On the epistemological level, genomics is often presented as a paradigm shift in the life sciences, a tremendous up-scaling of research, an "informatization" of life. Autobiographies may reveal how this shift usually discussed in more general terms from a philosophy of science or science studies perspective - manifests itself on an individual scale, on a microepistemological level. On the political level, autobiographies may inform us about the micro-politics of scientific change. Finally, on the level of Self, autobiographies may allow us to analyze how researchers, through practices of Self, are actively engaged in constituting themselves as responsible subjects in the face of unpredictable dynamics and unforeseen dilemmas.

Keywords: Human Genome Project; science autobiographies; micro-epistemology

\section{Introduction}

This article analyzes a number of recently published autobiographies by leading participants in the Human Genome Project (HGP), publications that may further our understanding of the history, scientific significance and societal impact of this major scientific endeavor. Notably, I will focus on three publications that fall under this heading, namely The common thread by John Sulston (2002/2003), The language of God (2006) by Francis Collins and A life decoded by Craig Venter (2007). Before

*Email: m.h.zwart@science.ru.nl 
presenting the objectives of this article in more detail, however, I will first briefly reflect on the relevance of autobiographies for science research in general.

Scientists communicate their views and findings through various genres, ranging from highly esoteric ones (notably academic papers in peer-reviewed journals) to much more exoteric ones such as interviews and public lectures. Whereas in the former scientific authors will justify themselves vis-à-vis their peer communities, in the latter they rather justify their role and work vis-à-vis broader audiences, or even society at large. This distinction between formal (peer-oriented) types of discourse versus more or less informal (public-oriented) ones has been framed in various ways. In their seminal sociological analysis of scientific discourse, Gilbert and Mulkay (1984) for example distinguish between "formal" (impersonal, highly conventionalized) and "contingent" (informal, personal) repertoires. While formal genres are open in principle to all competent researchers in a particular field, the use of exoteric (or contingent) forms of output (sometimes in co-production with science journalists or science writers) is usually a privilege (or an obligation) of a relatively small group of "visible" scientists, representing the larger research communities they are involved in.

This phenomenon, the coexistence of esoteric and exoteric genres within scientific discourse, also applies to research in the genomics field. Genomics has produced a plethora of formal academic papers, such as the Nature and Science publications announcing the completion of the "working draft" version of the human genome (IHGSC 2001, Venter et al. 2001), listing hundreds of "authors". ${ }^{2}$ Programmatic papers constitute another subgenre. They are written by a limited number of prominent researchers, leaders in their field - this goes for instance for the papers in which Francis Collins, in his role as director of the Human Genome Project, described and defined the evolving goals and ambitions of the "flagship project" of genomics research he was leading, as single author or in collaboration with a select number of co-authors $(1993,1998,1999,2003)$. Other genres belong to the contingent or exoteric side of the spectrum. They are explicitly directed towards (and accessible to) outsiders, such as newspaper articles, public lectures and interviews.

From 1990 onwards the Human Genome Project (HGP) as a large-scale, highly visible research endeavor has generated an enormous archive of documents: research papers, programmatic statements, journalistic coverings, CD ROMs, and so on. During the past few years, moreover, a particular kind of exoteric output has been added to this list, namely biographical and autobiographical publications. Documents of this latter type are interesting for various reasons. They focus on the "context of discovery", that is: on the "inside" of scientific research, ${ }^{3}$ on the internal dynamics of research communities and the psychology of scientific discovery. They reveal what often remains invisible or unsaid in more formal, academic publications (such as journal articles), focusing on the often unpredictable and hazardous vicissitudes of research work and its openness to societal, cultural and political influences. They may also reveal the sometimes decisive role of factors that have no place in the official methodologies of scientific research, such as friendship, animosity and rivalry, religion and dreams, strategic behavior and chance events. 
The question I wish to address in this article is: What may we learn from autobiographical sources about the dynamics of scientific change? What is their added value in understanding science in general and the HGP in particular? These questions will be elaborated in three directions: on the level of knowledge (epistemology), power (politics) and the Self (ethics). ${ }^{4}$ On the epistemological level, genomics is often presented as a paradigm shift in the life sciences, a tremendous up-scaling of research, an "informatization" of life. Autobiographies may reveal how this shift - usually discussed in more general terms from a philosophy of science or science studies perspective - manifests itself on an individual scale, on a micro-epistemological level. How does it become visible in real-life events? What does it imply in terms of the acquisition of new methodologies, theoretical outlooks and skills?

In terms of politics, the HGP is a large-scale project with high public visibility, involving complex policy networks, huge amounts of funding and controversial funding strategies. To what extent may autobiographies inform us about the micro-politics of scientific change, about the concrete actor networks as well as the responsiveness of leading scientists to policy agendas and politico-cultural trends?

Last but not least, autobiographies will highlight practices of "Self-formation". Generally speaking one could say that the basic objective of most autobiographies is a combination of self-understanding and self-justification. Authors will try to explain as well as justify their decision to spend so many years of their lives on a particular type of research by stressing the pivotal importance of their (often tedious) endeavors, for science as well as for society at large. They will try to assess or emphasize the importance of their own personal role, moreover, but usually they will also disclose and critically reflect on some of their basic failures and fatal flaws (lessons to be learned for future generations). Thus autobiographies may allow us to understand research as a "practice of the Self", that is: as a series of efforts directed towards transforming oneself (in terms of styles of thinking, worldview, lifestyle regime and so on) into a scientific individual that may effectively address the often unprecedented challenges of a dynamic field. They will also describe the (sometimes completely unforeseen) moral dilemmas researchers will have to face and come to terms with, as well as their ongoing efforts to acquire new sets of skills needed to function adequately and responsibly in increasingly complicated settings. ${ }^{5}$ Finally, autobiographies will often address, implicitly or explicitly, the issue of agency as such. To what extent can researchers involved in large scale and complex research environments really be regarded as autonomous choice-making agents? To what extent should they rather be seen as products of these practices, as individuals whose track records (both scientific and moral) are determined by factors that are beyond their personal control, as is suggested for example by John Sulston when he uses expressions such as "a chain of events was sweeping me along", or "The clang of the prison door reverberated in my ears" - indicating with this latter expression that, at a certain point, he came to realize how he had committed himself (knowingly or unknowingly) to a flow of events from which there would be no turning back.

The composition of this article is as follows. First of all, I will briefly assess the strengths and weaknesses of autobiographies as a source of information for 
understanding science in general and the HGP in particular. Next, a concise history of the HGP will be given in order to provide a backdrop for the subsequent analysis of the three main autobiographies published so far (by Sulston, Collins and Venter). ${ }^{6}$ How are issues of knowledge, power and the Self addressed by their authors? Finally, I will conclude with a series of reflections.

\section{Autobiographical sources: strengths and weaknesses}

The "classic" example of a biographical approach to science is Lives of the philosophers by Diogenes Laërtius, an important source of information concerning science and philosophy in ancient Greece. Interestingly, however, it has always been considered something of an embarrassment because of the shallowness of its philosophical content. There is an obvious contrast between the way academic life is presented by the scientists/philosophers themselves on the one hand (namely as a lofty endeavor of tremendous importance) and the light-heartedness of Diogenes' style on the other. His emphasis is on anecdotes, stories, weird habits, practical jokes, puns, etc. Apparently he was not so deeply interested in the technicalities and intricacies of the various truth claims involved. Science is described as a comedy. At the same time it is clear that Diogenes' accounts have really furthered our understanding of the more esoteric documents produced by the philosophers and their schools. This applies to the role of competition for example. Although the ideas of Plato, Aristotle and the Stoics have come down to us much better documented than those of their adversaries, Diogenes makes it clear that many of their ideas were actually formulated in the context of intense intellectual debates. Furthermore, although Diogenes often stresses the absent-mindedness and unworldliness of ancient researchers, he also highlights their political networks and PR activities. By stressing the human (or even all-too-human) dimension of intellectual activities, Diogenes allows us to add some detail to the images of scientific heroes as presented by more deferential sources. This, one could say, is a general feature of biographic materials. They reveal and bring into the open what tends to be forgotten or even consciously "repressed" in more formal self-presentations of science and scientists, where the focus is on grand achievements and key results, rather than on the novels of adventure that lead towards them.

A similar effect can still be discerned in one of the most famous science autobiographies of all time, namely James Watson's The double helix (Watson 1968/1996), a lively account of one of the highlights of the contemporary life sciences, in which the author casts himself as a "compulsively competitive, brash cynic" (Cook-Deegan 1994, 1995). It is the exoteric counterpart of The molecular biology of the gene, the textbook on which the author's impact as a scientist notably rested. The autobiographical self-image is clearly at odds with the lofty, disinterested, "Mertonian" ideal that is so often conveyed by textbook portrayals. In order to counterbalance popular images of laboratory work as tedious and dull, Watson wanted to redefine science in terms of competitiveness and rivalry, rather than "intellectual communism" and selflessness. Apparently, scientific competition justified a broad range of tactics (some of them controversial) that Watson and Crick applied in 
order to attain their scientific goal. Watson himself later emphasized that he had intended to tell the story "as if it were a novel, as opposed to a more conventional autobiography" (2000, p. 34) and as a "work of literature" (p. 35). ${ }^{7}$ Although the book became a best-seller and was heralded by literati for its literary qualities, those who wanted to preserve the academic ideal of selfless scientists pursuing knowledge for its own sake tended to dislike it. The inglorious self-image he projected, as well as the nickname that came to be attached to it ("Honest Jim") haunted Watson for life (Cook-Deegan 1994, 1995, p. 164). Moreover, his notorious difficulties in communicating (let alone collaborating) with eminent, talented and powerful women seems to connect what was more or less the beginning of his career (the Rosalind Franklin episode) with what was, in essence, the formal end (his unsolvable and highly personal conflict with Bernadine Healy, the director of NIH who virtually forced him to step down as Director of the HGP). Some biographies and autobiographies may even go a step further and reveal how apparently virtuous scientists, exemplars in their field, occasionally make themselves guilty of vices such as plagiarism, secrecy, disloyalty and deceit.

In various ways, the HGP mirrors the discovery by Watson and Crick of the structure of DNA in 1953, the beginning of the "classical period" in molecular biology, as Francis Crick (1988) phrases it - albeit on a much larger scale. On 2 April 1953, Watson and Crick published a concise two-page esoteric letter in Nature. Only scientists acquainted with their field could read and appreciate it. Since then, however, much broader audiences have been informed about the "carefree dawn" of molecular biology ${ }^{8}$ (before its transformation into Big Science), notably through autobiographical accounts. Beginning with James Watson, all the principal characters had their memoirs published (Watson 1968/1996, Crick 1988, Wilkins 2003), with the exception of Rosalind Franklin, who died too early, not only to receive the Nobel Prize, but also to produce an autobiographical account of her own. Yet, in her case, important biographical studies have been written (such as Maddox 2002/2003). ${ }^{9}$

A similar trend is now becoming visible with regard to the HGP. One by one, so it seems, the principal characters are coming to terms with the meaning of their project, and with the significance of their own personal role in it, in a number of biographical or autobiographical retrospects. This notably applies to autobiographical publications by Sulston, Collins and Venter, but we may reasonably expect that similar documents will follow in the near future. Examples of shorter autobiographical accounts by major players are Sanger (1988) and Hood (2002). Other publications containing important pieces of biographical and autobiographical information are The gene wars by Robert Cook-Deegan (1994/1995), Cracking the genome by Kevin Davis (2001/2002) and The genome war by James Shreeve (2004). The distinction between "biography" and "autobiography" is a fluid one. For example, although The common thread has all the genre characteristics of an autobiographical account, and is actually written in firstperson, the book was co-authored by science writer Georgina Ferry, thus constituting an intermediary form. Likewise, the genre status of Cracking the genome by Kevin Davies is not unequivocally clear. Presented as an historical account, the author (as founding editor of Nature Genetics) to a certain extent had been a protagonist himself, 
so that the book contains autobiographical elements as well. This also applies to Robert Cook-Deegan who, as a molecular biologist, co-author of $\mathrm{OTA}^{10}$ reports on genomics and executive director of BEAC, ${ }^{11}$ added interesting autobiographical reminiscences to the results of his desk research.

Although other contingent genres, notably interviews and public lectures, may also contain autobiographical fragments, ${ }^{12}$ these are usually highly context dependent and limited in scope. Full autobiographies tend to place personal experiences and insider descriptions of key events in a broader, more comprehensive perspective, adding depth and detail to what in other forms of output tends to remain fragmentary and superficial. Therefore, in comparison to the official channels and avenues of scholarly publication - and to a much greater extent than other contingent genres - biographies and autobiographies constitute an important complementary source of information for understanding scientific change. The history and pre-history of the HGP has now begun to generate an expanding series of autobiographical documents that open up important insights, but also invoke complicated controversies concerning the dynamics of science and its interactions with social and cultural environments.

In important respects, however, autobiographies are notoriously unreliable. In contrast to formal academic writing, they are not peer reviewed. Moreover, they should never be seen in isolation. As a rule, they constitute a kind of dialogue. For instance, they may actually be a response (implicitly or explicitly) to previous documents which the author sees as misrepresentations, consciously putting forward rival interpretations of important moments. Yet, this does not mean that in autobiographies anything goes. A number of checks and balances are in place. Visible scientists who intend to publish their autobiographical accounts will anticipate during the writing process that their book is likely to be publicly reviewed (often quite critically) in journals, magazines and newspapers and, at a somewhat later stage, that their work may even be scrutinized by historians of science. Moreover, it may be expected that other researchers in the field will respond sooner or later by publishing autobiographical reminiscences of their own, given the dialogic nature of the genre. In the Acknowledgements that often precede autobiographical publications, authors usually express their gratitude towards a substantial number of people for the comments made on previous versions of the manuscript. Thus, there actually is something like a peer review system at work, less formal and anonymous, compared to review procedures in the context of formal publications, but nonetheless quite intensive as a rule.

Still, for a variety of reasons, autobiographies have become a contested genre in the history, sociology and philosophy of science. From the 1970s and 1980s onwards, after the decline of existentialism so to speak, there has been a conscious shift away from studying the work of individual scientists towards analyzing networks, discourses and structures (Shortland and Yeo 1996). Science is no longer seen as the achievement of a series of "great men" (Ostwald 1909, Lenard 1933). Rather, knowledge claims are regarded as being produced by networks of more or less anonymous actors, so that any desire to focus on prominent individuals tends to be regarded with suspicion. ${ }^{13}$ 
This article must be seen as exemplifying a (dialectical) synthesis or "third wave" in the assessment of autobiographical documents. After focusing on scientists as heroes (at the expense of social context), and after subsequently dismissing individual-focused autobiographies from science studies altogether (in favor of a more sociological or structural approach), autobiographies are now used as complementary sources of information, valuable in their own right, allowing us to study scientific change not only on the macrolevel (describing science in general) or on the meso-level (analyzing particular research communities or institutions), but on the micro-level as well. Thus, they allow us to study transformations of knowledge production in a detailed, concrete and lively manner (how do paradigm shifts manifest themselves on an individual scale? To what extent do individuals perceive themselves as responsible agents in the face of largescale societal and technoscientific changes? How do they retrospectively assess and justify their personal investments in their research field?). In other words, rather than focusing "either" on individuals "or" on structures and institutions, a biographical approach will rather disclose processes of interaction and co-production between both dimensions. The HGP was made by the individuals involved no doubt, but the reverse is also true: the individuals involved were made by the HGP. ${ }^{14}$ Autobiographies are stories about individual persons, but they can also be seen as chapters in a collective "biography" of the HGP. Both dimensions should be given due attention in the context of a comprehensive view. Thus, the analysis of autobiographies generated by the HGP as undertaken in this article must be seen in the broader context of intellectual debates on agency and authorship. Nonetheless, the basic orientation of this article remains empirical rather than theoretical or methodological. To the extent that it contributes to theoretical reflections and discussions, it will preferably do so through a detailed analysis of the concrete materials at hand. I will return to these background issues in the final section.

\section{The Human Genome Project: a concise history}

The HGP was officially launched on 1 October 1990 under the leadership of James Watson. Its history can roughly be divided into three stages that also structure the biographies of its main participants. The first stage (1988-1992) was a period of development and implementation. It began with the appointment of James Watson at NIH in 1988 and ended with the latter's resignation. ${ }^{15}$ The second stage $(1993-1998)$ set in with the appointment of Francis Collins as Watson's successor. The HGP now really gained momentum. For the next few years, work on the HGP came to involve a relatively large number of research groups of varying size and sequence capacity. The human genome was divided into 23 natural subunits (the chromosomes) and research labs competed for funds in the context of the NIH peer-review system. In 1998, only 4\% of the human genome was sequenced in this manner. That same year, however, was a turning point in many ways and the beginning of the third and final stage (1998-2001).

First of all, former NIH scientist Craig Venter stepped forward to announce what seemed a hostile take-over, making the public program more or less redundant. Relying on automated sequencing machines and the whole-genome shotgun method, 
his privately funded Celera Company claimed to be able to sequence the human genome on its own, much faster than the public consortium had promised. The announcement was a direct challenge to the public effort and the latter responded by formulating a more focused strategy of concerted action. From now on the bulk of the work would be done by a limited number of avant garde labs with massive sequence capacity (this notably included John Sulston's Sanger Centre and Eric Lander's Whitehead Institute). ${ }^{16}$ These "major players" came to be known as the G-5. Starting off with a "pedestrian", loosely organized confederation of laboratories, Collins now had to redirect the bulk of available funding toward the most productive genome centers (Davies 2001/2002, p. 163). Moreover, it was decided that publication of a finished sequence would be preceded by a working draft version, a radical departure from the original plan (p. 162). Owing to this dramatic reorientation, the HGP was suddenly transformed into a "no-holds-barred race to claim the human blueprint". Indeed, it became a "crash project" (Lambright 2002). A dramatic competition ensued, eagerly covered by the media, until in June 2000 the "race" or "war" was suddenly declared over, as both sides agreed they were passing the line more or less simultaneously and Collins and Venter cordially made their appearance at the famous press conference at the White House in order to announce, in the presence of President Clinton, that the endeavor to sequence the human genome was nearing its completion. Both teams (Celera and the public consortium) sealed their truce by publishing working draft versions in a coordinated manner in February 2001, in Nature and Science respectively (IHGSC 2001, Venter et al. 2001) - although the fighting between representatives of both "armies" continued for some time in various settings. Finally, in 2004 the public consortium published its finished sequence (IHGSC 2004).

But the HGP cannot be truly understood if it is seen "in isolation". It must be placed in a much broader perspective, as a "flagship" symbolizing the emergence of genomics as a new techno-scientific field (IHGSC 2001, 2004). As Leroy Hood in his concise autobiographical retrospect describes it, the HGP brought to biology an entirely new approach: data-driven science as opposed to hypothesis-driven research. Elements of a biological system were placed in a database, thus changing how science was done by raising the possibility of comprehensive analyses (2002, p. 19). Or, as Walter Gilbert (1991) phrased it, genomics involved a shift from the "classic", small-scale experimental approach in biology (studying single genes as causal units) to a "new paradigm" that basically studied complex relationships with the help of high-throughput technologies and electronic databases. ${ }^{17}$ This shift has resulted in a steady stream of ever-larger and more complex genomic datasets, thus transforming the study of virtually all forms of life. Genomics is more than a new repertoire of tools. It aims to provide a more comprehensive understanding of the functioning of organisms in health and disease and has become "a central and cohesive discipline of biomedical research" (Collins et al. 2003, p. 835). In other words, genomics is not a particular branch of biology, nor merely a set of research tools for genetic data analysis. Rather, it is transforming the ways in which research in the life sciences is done. It is a transformation not only in terms of basic epistemological orientation (from gene hunting to whole-genome sequencing) ${ }^{18}$ but also in terms of science policy, involving a shift from investigator-initiated research 
(relying on peer-reviewed project grants) to massive program funding of coordinated efforts: "big science" (comparable in scale - and in various other respects as well - to CERN or the Apollo project in high energy physics and astronomy). Indeed, the HGP symbolized the emergence of a planned approach that was new to biology (Cook-Deegan 1994/1995, p. 178). Its impetus was no longer disease driven, but technology driven. Its basic objective was to establish an infrastructure for future research. Sequencing DNA was not experimental research in the traditional sense, but more like a massive construction project, comparable to building a network of highways or pyramids (Shreeve 2004, p. 19). ${ }^{19}$ Databases became an essential element in the pursuit of genetic knowledge (Shreeve 2004, p. 291). Molecular biology became a field where ICT and computation algorithms were crucially important. Reductionism was replaced by an emphasis on complexity, while the "intrusion" of computers into molecular biology shifted power into the hand of those with mathematical dexterity - the computer-literate (Shreeve 2004, p. 297). This explains the prominence in genomics of researchers with a background in ICT, mathematics and physics.

This shift is also reflected in the "war" between two funding agencies: DOE (the Department of Energy) and NIH (the National Institutes of Health) over the question which agency should coordinate the HGP. Whereas NIH represented the peer-reviewed, investigator-initiated grant system, DOE rather stood for big science. The latter agency had envisioned a few large production centers bent on sequencing the genome and developing the technology and computer power needed to make sense of all the evolving bioinformation. Instead, NIH set up the National Human Genome Research Institute to dispense funds through the peer-reviewed grant system to a loose community of academic labs around the country (Shreeve 2004, p. 43). In the history of the HGP, both strategies were more or less combined, but eventually the big science approach prevailed. How do these shifts manifest themselves on the micro-level? I will begin my analysis with the first autobiography in line, The common thread by John Sulston.

\section{Sulston: The common thread}

John Sulston has never been a prolific writer. He spent many years tracing, with the help of a special microscope, the development of all the 959 cells composing the body of the nematode worm Caenorhabditis elegans, the model organism of molecular biology selected by Sydney Brenner at Cambridge. In 1998, together with his friend and colleague Robert Waterston (Washington University in St Louis) he lead the "worm community" into sequencing its genome (The C. elegans Sequencing Consortium 1998). Moreover, as director of the Sanger Institute at Hinxton near Cambridge, privately funded by the Wellcome Trust, he made a key contribution to the HGP, both in terms of sequencing data and in terms of policy development. Interestingly, The common thread (2002/ 2003) has two main characters instead of one: not only John Sulston, but also Craig Venter, staged as antagonists in a moral battle. For although Sulston's book is a rich source of information concerning the HGP, it has other aims besides merely informing its readership about what actually happened, or recounting anecdotes about major protagonists. It sets out to tell the tale of a (close) moral victory. 
First of all, Sulston's book is the detailed account of a paradigm shift, a dramatic transformation of knowledge production and its impact on the micro-level. According to Sulston, genomics has transformed the way biology is done. It is "a watershed in the history of biology". He regards the sequence of the human genome as an incomparable tool for the investigation of every aspect of human function and as "a work of reference as indispensable to biologists as a dictionary is to a writer" (p. 278). Indeed, "somewhere in the genome will be the answer to what makes us different from all the other species - what makes us human" (p. 289). The HGP is regarded as "one of the most momentous enterprises in modern science" (p. 17). In a lively manner he describes how his own research practice changed (almost overnight) from tedious small-scale activities into a big science endeavor, stressing the sudden increase in scale and pace of the programs he was involved in and what this implied in terms of management skills and professionalization.

His own personal development is described as the (more or less sudden) conversion of a lone, somewhat withdrawn researcher (who avoided responsibility for anything other than his own work) into the manager of one of the largest research facilities in his field, forcing him to work in a much more organized way, to think much more politically and to invest much more time and effort in communicating with the outside world. ${ }^{20}$ Coming to terms with this dramatic up-scaling and acceleration of his research, as well as with becoming a "visible" scientist (a "minor celebrity" even) was clearly one of the motives for writing of his book. Indeed, a chain of events had been sweeping him along and by writing the book he wanted to better understand where it all had led to (p. 112). ${ }^{21}$ There is a sense of failure in his book as well. Apparently, at crucial moments, he was somewhat too reluctant and insecure to be successful in genome politics. He was not always able to respond to political opportunities or funding policy shifts that presented themselves. His basic flaw, as he defines it, was a certain lack of "megalomania". Although at a certain point he was heading the most advanced genome center worldwide (a center that could perhaps have undertaken to sequence the human genome on its own), he was eventually overtaken by other (more visible) protagonists: Francis Collins, Craig Venter and Eric Lander. ${ }^{22}$ This part of the "race" was lost. ${ }^{23}$

In Sulston's book the emphasis clearly is on moral justification. First of all, the book justifies the author's decision to devote so many years his life to studying C. elegans and sequencing model genomes. But more importantly, he emphasizes the importance and significance of his own personal role in a moral struggle between good and evil. Sulston literally states that this was his main reason for writing the book. ${ }^{24}$ The HGP story is presented in terms of a battle over "access to the most fundamental information about humanity", a campaign of those who wanted to keep the human genome freely available for research communities against the forces of evil who wanted to privatize it, turning "the common heritage of humankind" (p. 133) into a commodity. Where others (within the public consortium) wavered, Sulston stood his ground, firmly guarding the basic moral standards of science ethics, notably as the author of the "Bermuda principles". ${ }^{25}$ Indeed, it is obvious that the title, besides referring to DNA, also refers to a common threat, a danger threatening the human genome when it was about to be 
sequenced, personalized by Craig Venter. ${ }^{26}$ As Sulston points out, the prevailing ethos in the world of science had shifted. What was once a collective enterprise (in which discoverers were acknowledged but freely shared their results), is now frequently constrained by the demands of commercial competition. Yet Sulston (in his own view) made a significant contribution to keeping science public.

Craig Venter, the principal antagonist in Sulston's moral struggle, is someone that Sulston finds it difficult to deal with, in real life as well as (retrospectively) on paper. Morally speaking, Venter emerges in Sulston's book as a somewhat ambiguous figure. First of all, even Sulston has to confess that Venter is a superb scientist who contributed significantly to the field, for instance when his team sequenced and assembled the genomes of the bacterium Haemophilus influenzae and (together with an academic group) the fruit fly Drosophila melanogaster. On the other hand, he sided with private companies who had set their eyes on the human genome for their own profit. And this is precisely what makes Sulston so critical about Venter: he wanted to have "the best of both worlds", that is: recognition and acclaim for his scientific work from the scientific community, while at the same time accommodating the interests of business partners and enjoying the resulting profits.

The moral crusade of the public consortium against Venter's plans takes up a substantial portion of the book. It is not restricted to the issue of patenting, but also concerns issues of authorship. It is a principle of scientific publication that scientists must have access to the data supporting a paper's conclusions. As genomics often involves datasets too large to publish in hard copy formats, the relevant information is made available through GenBank. When publishing the draft version of the human genome in 2001, Celera was unwilling to follow that line, because it would amount to giving away valuable information to commercial competitors. After negotiations, Science agreed that Celera could publish its data on its own website, where academic researchers could download them if they agreed not to redistribute them for commercial purposes. This decision outraged the public consortium. It withdrew its paper from consideration at Science and submitted it to Nature instead (Shreeve 2004, p. 362). For Sulston, this was a decisive moment: "Would Science or Nature accept a paper on conditions that fell so far short of their own guidelines? If either did, it would be a very serious matter for science as a whole. Scientific journals are critical to the integrity of the whole enterprise of science" (p. 256). While Science conceded, Nature steered a more principled course and was awarded the honor of publishing the public program's draft version. This was, according to Sulston, another important moral victory: "We had taken a stand for freedom and information and integrity of scientific publication. What Science had done was unethical to us" (p. 264). ${ }^{27}$

\section{Collins: The language of God}

When Francis Collins was appointed as director of the HGP in 1993, he already had an impressive track record as a gene hunter (cystic fibrosis, neurofibromatosis, Huntington's disease). Moreover, his clinical skills made him sensitive to the potential impacts of bioinformation on future health care (Cook-Deegan 1994/1995, p. 342). Besides 
research papers he published or co-authored a number of influential programmatic papers on genomics and the HGP, often focusing on societal and (in particular) biomedical consequences. ${ }^{28}$ Finally, he published and lectured on the compatibility of science with religious beliefs.

Francis Collins led the HGP from 1993 onwards as director of the National Human Genome Research Institute (NHGRI). The highlight in his career was on 26 June 2000, when together with President Bill Clinton and Craig Venter he announced that the deciphering of the human genome was rapidly approaching its completion. Clinton stated on this occasion that "today, we are learning the language in which God created life". In his book Collins not only discloses that he acted as Clinton's ghost-writer, urging the latter to include these lines $(2006$, p. 3) - he also explains his reasons for doing so. For him, DNA really is the language of God. ${ }^{29}$ The book is his "coming out", so to speak, as a born-again Christian. He saw the announcement on 26 June as a moment of religious significance, a religious "celebration", an "occasion of worship". This aligns in many respects with statements in his programmatic papers on genomics as a revolution in science. Collins regards human DNA as sacred Scripture, the human genome as "the book written in the language by which God spoke life into being" (2006, p. 123). The experience of sequencing the human genome, uncovering this most remarkable of all texts, was "both a stunning scientific achievement and an occasion of worship". The human genome cannot be the outcome of anonymous natural processes only: "DNA ... seems an utterly improbable molecule to have "just happened"' (p. 91). Indeed, Collins confesses that he is "in awe of this molecule" (p. 102).

In comparison to the books by Sulston and Venter, the political or power dimension is hardly worked out in Collins' case. The focus is unequivocally on the question how to combine his religious worldview with science. How can a religious understanding of the human genome concord with a scientific view on life? For Collins, the starting point for developing a religious worldview is the susceptibility of human beings to moral experience. Evidence for the existence of God is not found in evolution. In principle, this can be seen as a completely autonomous process. For Collins, there is no "argument from design". Evidence for the existence of God comes from our openness to moral experiences of conscience and calling. It is only subsequently that the question emerges how these experience can be connected in a convincing way with the facts of evolution.

This concept of our openness to moral experience is worked out in an autobiographical manner. The request to become Watson's successor took Collins by surprise and he was a reluctant recruit, finding the idea of being entrusted with the task of leading such an extremely complicated research endeavor as "absurd". It seemed much too big for him, something far beyond his capacities and abilities. But then he had second thoughts. Could it be a divine assignment, a moment of calling? Could it be that this was "one of those moments where I was somehow being called to take on a larger role in a project that would have profound consequences for our understanding of ourselves? Here was a chance to read the language of God, to determine the intimate details of how humans had come to be ..." (pp. 118-119). Collins describes how, in November 1992, he spent a long afternoon praying in a little chapel, seeking guidance concerning this 
decision. During those hours, "ending in an evensong service that I had not expected, a peace settled over me. A few days later, I accepted the offer ..." (p. 119). It is through moral experiences of this kind that the presence of God manifests itself to us. God is not obviously present in the universe. On the contrary, inserting the existence of God into a scientific worldview is a difficult task - but, according to Collins, not an impossible one.

In other words, justification is once again crucial in this book, on two levels. First of all, on the personal level, the experience of calling justified him to accept his role in upscaling science. But the book also sets out to justify the HGP as such. In Collins' view, there are three decisive milestones in the history of the world: the Big Bang (the beginning of the universe), the emergence of life (of DNA) and the emergence of human life, that is: the emergence of human conscience and self-consciousness. The unveiling and understanding of these major "events" constitute the three highlights of discovery. And this explains why Collins believes the HGP to be such an outstanding milestone in the history of unveiling nature.

Initially, the emergence of homo sapiens does not seem to stand out as something astonishing, in comparison to the emergence of being and the emergence of life. Humans are not that different compared to other life forms. There is evident continuity and similarity with other species. Yet, Collins argues, the importance of the coming into being of humankind resides in our unprecedented openness to the world around us, our openness to experiences of responsibility and calling, as well as our unprecedented ability to question and reconstruct our own position in the world, our own origins. This assessment of the importance of humankind also has evident repercussions for Collins' understanding of the HGP and of himself. It justifies the decision of congressmen and funding agencies to invest huge amounts of public funding in this endeavor. But it also gives meaning and focus to Collins' own personal life, from his decision to migrate from physics to biomedicine up to his decision to accept leadership of the HGP: an epistemological opportunity that presents itself only once in a lifetime - in a millennium even. ${ }^{30}$

\section{Venter: $A$ life decoded}

Craig Venter became a highly visible figure when, in 1998, he challenged the public program by announcing to produce a sequence of the human genome must faster than was originally planned. Initially, James Shreeve's The genome war (subtitled "The inside story of Craig Venter's race to sequence the human genome") was partly meant as a biography of Venter, but eventually, the latter decided to write his own version (Venter 2007, p. 359). ${ }^{31}$

A life decoded reads like a novel, a science epic. It is, in its author's own words, "a tale of seemingly impossible quests and grand objectives", of "great rivalries and bitter disputes", of "battles of ideologies, morals and ethics" and of "clashes of egos" (p. 2), an adventure that swept the author "from peaks of incredible exhilaration as I marshaled a relatively small but dedicated army of scientists, computers and robots to achieve what seemed almost impossible, and then plunged me into black pits of depression as 
I faced opposition from Nobel laureates and senior government officials, my colleagues, and even my wife" (p. 2). Moreover, besides being an autobiography proper, the book also contains a series of reflections on genes present in the author's own genome, one of the first individual genomes that was sequenced and made publicly available on the web - the "recipe" that made Craig Venter, as he himself describes it. In separate boxes dedicated to his sequenced genome, he especially focuses on genes that are associated with behavioral characteristics such as thrill-seeking behavior, ADHD and the ability to cope with almost superhuman amounts of stress. Thus, in Venter's case, autobiography and the human genome are interconnected in more than one way.

His autobiography is built along three co-evolving strands: career, marriages and sailing. Major career shifts are associated with similar events in the other dimensions. A number of career stages can be distinguished, separated from one another by dramatic changes, and these stages roughly correspond to changes in terms of marriage partners, sailing boats and physical appearance.

During the first stage Venter works on adrenaline receptors as a university researcher at UCSD La Jolla and in Buffalo New York. He is married to Barbara Rae and wears long hair and a long beard. We find him sailing, preferably on a catamaran, first at Mission Bay and later on Lake Erie and Lake Michigan.

From there - stage two - he migrates to the NIH headquarters (Bethesda, Maryland) to become a prominent intramural NIH researcher, moving from adrenaline receptors to the adrenaline receptor gene, marrying fellow researcher Claire Frazer and sailing the Atlantic from Chesapeake Bay, notably to the Bermuda islands. He describes it as a turning point in his career: "I had left a safe field in which I had become comfortably established and taught myself and my team a new discipline, molecular biology" (p. 100). His physical appearance changes dramatically as well. He has become bald, corpulent and beardless. And it is from this position that he becomes involved in the genomics revolution, "transforming the analog world of biology into the digital world of the microchip" (p. 100). Human genomics offers sufficient allure to encourage him to make a leap into the unknown: "I decided I would build a new career in the emerging field of genomics" (p. 109).

After a period of frustration ${ }^{32}$ he decides to set sail once again, both literally and figuratively. An adventurous sailing trip to Bermuda, a highlight in his sailing career, also marks his decision to leave the public human genome effort and to start a research institute of his own, based on his EST method and the whole-genome shotgun approach - the third stage: "Bermuda would mark the beginning of a battle for survival in which my science, my marriage and my reputation were at stake. When that voyage ended I had sequenced the genome and felt the same visceral thrill $\mathrm{I}$ had experienced sailing to Bermuda" (p. 115). Initially he sets up TIGR, but after a prolonged battle for survival with business partner William Haseltine of Human Genome Sciences, his wife Claire Fraser takes over as acting president of TIGR, while Venter himself embarks on a new venture, Celera, financed by a company that produces the automated sequencing machines. Celera is set up not as a biotech company, but as an information company, symbolizing the industrialization of biology and the informatization of life, and meant 
as a portal to bioinformation for universities, companies and eventually even for individual citizens, with the intention of empowering them to manage their own health condition on the basis of their genome. ${ }^{33}$ From this position he begins his highly visible and widely discussed competition with the government effort, the International Human Genome Sequencing Consortium, headed by Francis Collins.

From that moment on, the story really gains epic momentum. Venter becomes totally immersed in and addicted to his grand project. With his marriage deteriorating, the only refuge left to him is an occasional oceanic sailing voyage. Finally, having first sequenced the genomes of Drosophila melanogaster and some other model species, the famous White House press conference takes place, announcing that the human genome effort is reaching its completion, and the heroic tale of both collaboration and competition reaches its climax with the coordinated publications in 2001. But Venter's career is far from over. A new sailing adventure, this time to the Caribbean, marks a new transition in his life, towards a fourth stage, as "Each major transition in my life has been accompanied by a new sailing adventure with an expanded horizon" (p. 330). He decides once again to build a new research effort from scratch and becomes a geographer of life. Once again, his appearance changes accordingly. Business suits give way to outdoors clothing and once again he grows a beard. His sailing vessel Sorcerer II becomes a floating observatory. After his divorce from Claire Fraser, he now marries Heather Kowalski.

The focus now shifts from sequencing the genomes of model species (such as Homo sapiens) to sampling the metagenomes of aquatic ecosystems. The final chapter of $A$ life decoded contains a plethora of images connected with exploring our "blue" - that is, aquatic, rather than terrestrial - planet, taking genetic snapshots of ocean life, thus sequencing "the genome of the ocean itself" (p. 343), and opening up new realms for human exploration and understanding. The use of aquatic metaphors, linking genomics with ocean sailing, is significant in many respects. Since time immemorial the sea has functioned as an image of liberation from obstacles, of freedom, movement and openness of thought, migrating beyond the sway of established institutes. Whereas Francis Collins in his White House speech identified himself with the "trusted aid" Meriwether Lewis who, sponsored by the US government, set out to map unknown terrestrial territories as part of a process of annexation and colonization, Venter is eager to associate his work with embarking and setting sail, to places where one is left to one's own devices (also in terms of funding) and "where there is still an ocean of great science left ... to explore" (p. 357), discovering new worlds, breaking away from entrenched positions. In Venter's view, science is an endeavor that takes us "far from shore into unknown waters" (idem). It defies, rather than reinforces or expands, established terrestrial authorities.

The major epistemological tension between Venter's approach and the ideas of the public consortium concerned the role and scope of computational biology as well as the way in which the new bioinformation science was to be aligned with the established standards of scholarly publication. Venter opted for a controversial technique that went under the name of "whole-genome shotgun approach", hoping that a powerful algorithm, in combination with the availability of a giant computer, would allow a reassembly of 
the sequenced fragments into a full version of a human genome. From the outset, prominent representatives of the public program had been highly skeptical of this idea, but it was successfully tested on a bacterium (Haemophilus influenzae, 1995) and on Drosophila melanogaster (1999).

Initially, there was considerable suspicion and opposition among biologists to largescale sequencing by automated sequencers, ${ }^{34}$ yet throughout the 1990 s Venter repeatedly showed that he could indeed do just what the genetics establishment said he could not (Papineau 2004). In two years' time, Venter transformed from a solid, respectable scientist working for the federal government into a stunningly successful, fabulously wealthy entrepreneur with a high media profile (Davies 2001/2002, p. 67). His meteoric rise to fame and fortune made him an obvious target for his many enemies (p. 66).

In terms of "science politics", Venter was active on two "fronts": both academia and business. He wanted to excel in both: making money through filing patents, while yearning for academic credit through watershed scholarly publications. Venter's string of genome publications in the 1990s made him one of the most highly cited researchers while his comparatively small teams produced a staggering amount of data. This double agenda led to fierce opposition from both sides. Yet he is credited by many for up-scaling and accelerating the pace of genomics research and has always been highly in demand as a public speaker.

Moral justification is an important element in Venter's case as well. His war experiences in Vietnam, triaging troops to identify salvageable lives (Davies 2001/2002), was his moment of "conversion". His ultimate aim, however, was not that of saving lives, but rather to become the Darwin of the bioinformation age, accumulating genomes in order to revisit the history of the earth and improve its prospects for the future.

\section{Reflections}

Autobiographies constitute valuable sources of "complementary" information, describing complex transformations in knowledge production in minute detail on the level of micro-epistemology and micro-politics. Yet, to what extent can they be regarded as "truthful" and reliable accounts? Besides providing "inside" and anecdotal information about what "really" happened, autobiographies usually contain a number of moral messages as well, placing facts and events in a particular perspective. A rather common one is that, in order to achieve scientific excellence, one has to persevere, even in the face of biased opposition and apparent failure. Yet, more specific moral messages are present in autobiographical materials as well, attempts to reframe a number of decisive events in genomics history.

Sulston's book is a valuable source of information, but also a continuation of the war against Venter by different means. ${ }^{35}$ After the competitive struggle to sequence the human genome had come to a "happy ending", the no less competitive struggle over the question how this episode (and the roles of the various participants) should go down in history and should be morally assessed by future generations remains intense 
up to this day. ${ }^{36}$ Sulston's book relies on a basic normative scheme, a moral dichotomy (right vs. wrong) that in the end seems difficult to sustain. Eventually, Sulston's own book demonstrates that human realities are too complex and ambiguous to be reduced to such a binary view. Rather, we should say that all participants were faced, sooner or later, and to a greater or lesser extent, with similar normative challenges. All participants were forced to position themselves, to constitute themselves as moral subjects, on an emerging continuum. While some took a more radical position, others opted for a more moderate one, and still others gradually changed their minds, but we cannot meaningfully split the world of the HGP into two moral "halves", the good and the bad. For instance, as I already indicated, rather than representing a full-fledged commercialization of science, Craig Venter occupied a somewhat intermediate position. He too fought his battles with the more radical representatives of the commercial approach, such as William Haseltine (CEO of Human Genome Sciences) or Tony White (CEO of Perkin-Elmer), while contributing significantly to the amount of genomics data that were freely and publicly available for all researchers to consult. According to Venter, the war with Sulston was not a conflict over free access to bioinformation. His research methods and sequencing capacities, rather than his dissemination strategies, were seen by Sulston as a threat. In Venter's version, Sulston "panicked" when he discovered that he no longer represented the largest genome center in the world (p. 242). Moreover, Venter was not the only scientist who tried to combine academia with business. Walter Gilbert (Myriad Genetics) and a number of other prominent researchers did the same. And to some extent, this goes for all participants. Involvement in gene patenting is widespread among the research communities that contributed to the HGP, including Francis Collins. And James Watson resigned as director of the HGP not only because he publicly endorsed a reluctant view on valorization (patenting of genes), but also because of a conflict of interest (Bernadine Healy wanted him to sell his stocks and holdings). Watson was not in principle opposed to filing patents on genomics data. His conflicts with Healy were of a personal rather than of a principle nature. ${ }^{37}$

Even Sulston himself was funded by a private institute - a non-profit one, that is true, but the Wellcome Trust money eventually came from commercial sources (the legacy of the American-born pharmaceutical magnate Sir Henry Wellcome). And in 1993, even John Sulston himself had his round of negotiations with commercial headhunters. The wealthy US entrepreneur Frederick Bourke wanted him and Robert Waterston to become the principal investigators of a commercial project for human genome sequencing. ${ }^{38}$ In fact, the risk of a brain drain was a major reason for the Wellcome Trust to set up the Sanger Centre at Hinxton. Had the Wellcome Trust not stepped in, Sulston's book may have had a different plot, as well as a somewhat different moral message.

Another intriguing issue is the gender dimension of the story. All the biographical documents generated by the HGP so far focus on males. At the same time, it is clear that, in all of them, sooner or later powerful and talented women emerge that play decisive roles, not only in the HGP as such, but also in the careers of the principal protagonists themselves. Bernadine Healy, already mentioned, forced Watson to step down (a major feat given the latter's tremendous prestige and informal power as the most 
famous biologist of his time and as a person with strong and extended networks, in science, politics and the media) and appointed Francis Collins: an important turning point for the HGP. For Watson had more or less already played his cards and from that time onwards, the HGP really gained momentum. Venter, as a close (albeit not impartial) witness, describes the Watson-Healy conflict as a "clash of titans": the world's best-known molecular biologist versus the most powerful administrator of biomedical research. ${ }^{39}$ In his assessment of their conflict he stresses Watson's "lessthan-stellar" management qualities as well as the latter's indirect and informal ways of communication in combination with his prejudices towards women. Eventually, Venter summarizes his view as follows: "I ... always found her [Healy] to be an effective leader. I suspect that many of the attacks against her said more about the stodgy, male-dominated NIH establishment attitudes towards a relatively young and attractive female than about her actual abilities" (p. 155).

In the case of John Sulston, Judith Kimble emerges, not only as an important and excellent researcher, but also as someone who, for many years, as Sulston phrased it, "organised me" (p. 89). Finally, Craig Venter was, during the decisive years, the visible half of a powerful league with Clair Fraser, his wife and scientific partner. Indeed, their relationship was the academic version of the one between Bill and Hilary Clinton. Fraser was a prominent genomics researcher and research manager in her own right with an impressive curriculum. Their marriage reflected the combination of competition and collaboration that characterized the HGP during the decisive stage. Venter's subsequent spouse Heather Kowalski had a quite different, more supportive and subservient profile. Before the start of their relationship, she acted as his communication officer, in charge of his public relations. In that role, she became his "constant travelling companion and advisor" (p. 292). In conclusion, the HGP more or less reflects the stereotypical pattern of the powerful woman, supporting, challenging, inspiring, etc. a visible male hero, but remaining somewhat less visible herself.

Interestingly, the various versions of the HGP story contain incommensurable assessments of a number of highlight events, such as the famous press conference announcing the completion of the HGP on 26 June 2000. Francis Collins describes it in the opening lines of his book as follows: "On a warm summer day just six months into the new millennium, humankind crossed a bridge into a momentous new era. An announcement beamed around the world, highlighted in virtually all major newspapers, trumpeted that the first draft of the human genome, our instruction book, had been assembled" (2006, p. 1). Indeed, in Collins' view, it was a moment of epochal significance ${ }^{40}$ as in his view the HGP had taken on "messianic quality" (Shreeve 2004, p. 20). Yet, in the opening lines of Davies' version, this same event is described in completely different terms: "In June 2000, Venter and Collins reached a fragile truce, ${ }^{41}$ paving the way for the hastily contrived, hopelessly premature ceremony at the White House" (2001/ 2002 , p. xv). According to Davies, the "shared victory" announcement was premature in many ways: Collins's consortium had not quite reached their stated target of a "rough draft" of $90 \%$ of the sequence (Davies 2001/2002, p. 6) and with just days to spare before the White House declaration, a graduate student at the University of 
California (Jim Kent) was still finishing a computer program to order their DNA fragments. As critics argue, there was an element of "fake" or even "fraud" in this event. It would take another four years before the sequencing of the human genome was really finished. In other words, whereas according to Collins (and others) the White House ceremony was a highlight in recent science history, skeptics rather saw it as a PR activity in which results were being claimed that had not really been achieved - "science by press release". And while Sulston called the event "dishonest", Venter felt proud, emotional and "elated" (p. 312). Sulston had his reasons for being angry: while Celera was prominently represented, his Sanger Institute was not even mentioned.

In terms of science politics, it is not without significance that the HGP and the Clinton administration (1993-1997; 1997-2001) more or less coincided. In 1993, in the same year in which Collins was appointed as director of the HGP, Clinton was elected president of the United States. His administration was supportive of the HGP from the start. To Clinton, the HGP was what the Apollo project had been for President Kennedy. And in 2000, when his presidency was facing a major crisis, Clinton was urgently in need of a story that could improve his image. In fact, the interests of all participants converged in the event. Collins needed the ceremony to secure public funding, while Venter was having more difficulties with sequencing and assembling the human genome than he had expected. Moreover, each side was "hostage to the danger that the other would suddenly orchestrate a fanfare and declare itself the winner - and in a way, that is pretty much what happened, except that they did it together" (Papineau 2004), although both admitted that their announced results were far less polished than originally intended and that, in the flurry to meet the deadline, both sides had been cutting corners.

Collins' reasons for highlighting this event, however, were not merely strategic. Rather, they were connected with his religious worldview. For Collins, the universe was created in such a manner that, somehow, life could come into being and, eventually, human life could emerge. A similar teleological structure is reflected in the history of science, even on the micro-level: in a science biography. His directorship of the HGP is framed as an event that put his whole academic track record in a meaningful perspective: "My whole career has been spent training for this job", as he himself phrased it (2006).$^{42}$ From Collins' point of view, the White House celebration really was an important moment of celebration and reflection, allowing us to see and celebrate the broader, meaningful pattern in what for others is likely to remain a chaotic series of chance events.

This is directly related to another issue: to what extent has the HGP changed the way we view ourselves in relation to other species and to nature as such? To what extent has it forced us to redefine ourselves? Sulston, Collins and Venter all reflect on the fact that our genome "only" contains 22,500 genes and apparently has much more in common with the genomes of other species than was initially expected. While Venter interprets it as the end of genetic determinism and the emergence of a more advanced view on the relationship between genetic endowment and behavior (the nature-nurture debate), Sulston denies that it has much relevance for this debate at all. ${ }^{43}$ As for Collins, who writes about this issue rather extensively, it confirms that our uniqueness does not reside in our genome, but rather in our openness to the moral dimensions of life, our 
ability to really make existential decisions. "Many of us were stunned to discover that God writes such short stories about humankind" he confesses (2006, p. 125), and some have taken this "as a real insult to human complexity" (idem). Yet, "no other organism has sequenced its own genome!" We are special because we are willing an able to question our descent, our biological past and future and (according to Collins) this can only be explained in a religious manner.

Finally, as was indicated in the Introduction, autobiographies are seen by many as constituting a problematic genre because of the focus on the initiatives, dilemmas, decisions, experiences and responsibilities of individuals, rather than on the social dynamics of research communities. They highlight the vicissitudes of a limited number of highly visible participants, rather than the investments of large numbers of anonymous researchers. Yet, to some extent autobiographies prove to be remarkably self-corrective in this respect. First of all, in all the autobiographical documents consulted in this paper, the issue of agency is addressed explicitly and in a fairly sophisticated manner. Rather than presenting themselves as heroes of science, in full control of the events, Sulston, Collins and Venter all emphasize, each in his own vocabulary, how they see themselves as team workers, and even more so as products of the HGP. All three authors describe in a lively manner how they, notably at crucial moments, were "pulled", "swept" and "driven" by the events, how they, at certain points, "plunged" into complex schemes the outcome of which were impossible to predict from an individual perspective. Thus, autobiographies analyze the co-evolution, so to speak, of individual researchers and social dynamics and we cannot say that primacy is given to the former.

Furthermore, whereas from a distance the HGP may seem like a paradigm of science management, a micro-analysis of autobiographical materials is bound to reveal that the experiences of those closely involved in it were experiences of unpredictability, uncontrollability, sheer chaos even, rather than experiences of optimal "planning and control".

Moreover, after reading the reminiscences of Sulston, Collins and Venter one is bound to realize that, although their role was important, it was limited as well. After reading Venter and Shreeve on Celera, for instance, it is clear that in various respects, researchers like Gene Myers, Mark Adams or Hamilton Smith were at least as important in terms of decisive scientific contributions as their spokesman. Although the temporary focus on individual experiences may refine our understanding of knowledge transformations, they eventually become embedded again in a more comprehensive view. What CookDeegan stated with regard to one particular chapter of the HGP evidently applies to the project as a whole: "the final truth is that no individual can take full credit" (1994/1995, p. 70). Indeed, as he argues, Nobel selection committees are "perpetually unfair" in conferring a prize on "winners" in science - ignoring the way science has changed so that most major advances require the efforts of hundreds of researchers, not one or two. This is affirmed by Collins. When he was asked at a press conference in San Francisco, February 2001, whether the sequencing of the human genome warranted the Nobel Prize he replied that it would have to be given to 3492 people to 
properly recognize everyone who had significantly contributed to this common effort (Davies 2001/2002, p. 266). Although somewhat rhetorical, no doubt, autobiographical documents reveal that there is a kernel of truth in his reply.

\section{Notes}

1. Sulston's autobiography was co-authored by science writer Georgina Ferry.

2. Their anonymity was stressed by the conscious decision not to put names on the title page: "the author would be simply the International Human Genome Sequencing Consortium" (Sulston 2002/2003, p. 260).

3. Cf. the subtitle of Davies (2001/2002): "inside the race to unlock human DNA"; or the title of the review by Papineau (2004) of Shreeve (2004): "Speed-reading the book of life: the inside story of Craig Venter's race to sequence the human genome". Also Sulston presents his book as an "insider's view".

4. This scheme, indicating three "axes" or dimensions of research, builds on Foucault (1984).

5. Cf. for instance "I myself knew very little biology ... till I was over thirty. It took me a little time to adjust to the rather different way of thinking necessary in biology. It was almost as if I had to be born again" (Crick 1988, p. 6).

6. This article builds on my reviews of the autobiographies of Collins (Zwart 2006) and Venter (Zwart 2007) published earlier in Genomics, Society \& Policy.

7. This was also conveyed by the original title, Honest Jim, building on literary precursors such as Lord Jim and Lucky Jim.

8. An epoch reminiscent of the golden age of physics in the early part of the century (Gratzer 2000, pp. xvii-xix).

9. Other important biographical sources on this chapter in science history are Judson (1979) and Jacob (1987/1988).

10. Office of Technology Assessment.

11. Biomedical Ethics Advisory Committee.

12. Cf. for example the "autobiographical" lectures that make up a substantial part of Watson's autobiographical A passion for DNA (2000, p. 49).

13. Bruno Latour's The pasteurisation of France $(1984 / 1988)$ has been referred to for instance as a Hamlet without Hamlet, since the hero whose name is referred to in the title is virtually absent in the book (Shortland and Yeo 1996).

14. Cf. the famous remark by Francis Crick that it was not he and Watson who made DNA, it was DNA which made them (Watson 2000, p. xvii).

15. 10 April 1992.

16. "If the public program was to compete with Venter, it would no longer be feasible to have so many separate entities involved in the decision making. The project would have to become more centralized and streamlined. The people who had proven that they could deliver efficiently would have to get a bigger slice" (Shreeve 2004, p. 126).

17. "The world of biomedical research will be divided into two halves: the gene-by-gene, clone-by-clone approach that marked the first half, and the global, population-based, genome-centred analysis that will dominate the second" (Davies 2001/2002, p. 250).

18. "The push for the genome ultimately came from molecular biology rather than genetics" (Sulston $2002 / 2003$, p. 81); cf. "Anyone who was serious about genomic sequencing as opposed to those who were simply sequencing genes" (p. 165); see also Cook-Deegan (1994/1995, passim).

19. The DOE had envisioned a few large production centres bent on sequencing the genome and developing the technology and computer power needed to make sense of all that information. Instead, NIH set up the National Human Genome Research Institute to dispense funds through the tried-and-true, peer-reviewed grant system to a loose community of academic labs around the country. 
20. "I had not learned to be a manager ... [but] going into sequencing was going to lead a big management structure". Cf. "Many of the extra genes that are added in going from worm or fly to human appear to be control genes, and they come in hierarchies ... It is a bit like the expansion of an organisation: although some of us wish it wasn't so, an essential part of building up a large organisation is the introduction of more complex management structures and the employment of more executives. The control genes are the executives of biological development, and they allow complex and diverse structures to be built from units that are fundamentally quite similar" (p. 279).

21. 1989. "The clang of the prison door reverberated in my ears. It was one of the most exciting moments in my life" (p. 14).

22. "Eric Lander came up on top. We had missed our moment. Everything was now in place for the Whitehead Center to become the biggest".

23. "We had missed our chance ... erring on the side of caution" (p. 158).

24. "Today any scientist anywhere can access the sequence freely at no cost and use the information to make his or her own discoveries. We wrote this book so that people might understand how close the world came to losing that freedom" (p. 9).

25. Requiring free and rapid data release by submitting annotated sequence to GenBank for unrestricted access on a daily basis - thereby making patenting impossible.

26. When Celera was launched, "the whole future of biology came under threat... Any scientist anywhere can access the sequence freely at no cost and use the information for further discoveries. We wrote the book so that people might understand how close the world came to losing that freedom" (pp. 8-9); "The Venter plan was a potential threat to the whole genome project" (p. 175).

27. Sulston is also critical of Venter's eagerness to go public - "science by press release". According to Sulston, the convention is that one should not announce results until the work is completed and accepted for publication. Yet, one could say that this also applies to the famous press conference announcing the completion of the human genome sequence - more than three years ahead of schedule.

28. This not only includes "A vision for the future of genomics research" (Collins et al. 2003) but also the final pages of the 2001 publication on the working draft version of the human genome.

29. "For Collins the code was part of the unimaginably immense knowledge of the Creator. Uncovering its sequence would provide a glimpse into the nature of God's mind" (Shreeve 2004, p. 20).

30. "There is only one human genome program... It will only happen once, and this is that moment in history" (cited in Shreeve 2004, p. 17).

31. Although Venter is the main character no doubt, Shreeve's book actually became a biography of Venter and his team.

32. As he explained in a letter to James Watson: "I am concerned that the bureaucracy that is a necessary part of the grant review process cannot keep pace with the rapid developments in the genome area" (Cook-Deegan 1994/1995, p. 315).

33. Celera's mission was "to become the definitive source of genomics and medical information in the world" (Shreeve 2004, p. 172). As Venter emphasized, Celera was not a "biotech" but an "information company", comparable to LexisNexis and providing genomic information on a global scale. Celera's flagship project would be a massive database of DNA with the human genome sequence as its heart (Shreeve 2004, p. 120).

34. "Most biologists vehemently opposed the HGP ... [They] felt that since only $2 \%$ of the genome was presumably genes, it was a waste of time and money to sequence the entire genome. Moreover, since the HGP was not hypothesis-driven, most biologists felt it was not real science" (Hood 2002, pp. 19-20).

35. "The torrid criticism of Celera continued unabated with the publication in the United Kingdom of Sir John Sulston's book The common thread" (Davies 2001/2002, p. 265).

36. As a rule, autobiographies can often be regarded as responses to certain publications or certain events. For example, although the famous White House press conference that plays such a prominent role in the retrospects by Collins and Shreeve is treated almost as an aside by Sulston, it may well be that one 
of his reasons for writing the book was to reposition himself as one of the decisive factors, next to Collins and Venter, as during the press conference he had been treated as a figure of secondary importance.

37. In their conflict, gender was much more important than commercialization. One of the things Watson said about the NIH director was: "The person in charge of biology is either unimportant or a woman. They had to place a woman someplace" (Venter 2007, p. 328) - a comment that not only angered Healy, but is also quite at odds with her impressive academic and managerial track record; I will come back to this later.

38. "Given our commitment to the public domain, the fact that Bob and I even considered heading up a commercial organization needs a bit of explanation ... We were very unclear in our own minds whether either of the funding agencies on which we depended was going to come up with the money we would need ... So we were very open to exploring other possibilities" (pp. 99-100). Cf: "As biologists we had lost our innocence. We were out in the so-called real world. The environment of biology [had changed]" (Sulston 2002/2003, p. 209).

39. Cook-Deegan describes the conflict between James Watson and Bernadine Healy in similar terms as a conflict between "the two most powerful figures in biomedical research. Watson was the most famous molecular biologist of his day and Healy the most powerful biomedical research administrator" (1994/ 1995, p. 326).

40. "The majesty of the enterprise itself. In Collins's words, the project had taken on almost messianic quality, a noble, historic undertaking that dwarfed going to the moon" (Shreeve 2004, p. 20). Cf. the line already cited: "There is only one human genome program ... It will only happen once, and this is that moment in history" (Shreeve 2004, p. 17).

41. Thereby putting an end to the "genome war" (Shreeve 2004).

42. "My whole career has been spent training for this job - this is more important than putting a man on the moon or splitting the atom" (cited in Davies 2001/2002, p. 69).

43. "The question is: should it make a difference to our thinking whether we have 30,000 or 100,000 genes? I think the answer is no" (p. 278).

\section{References}

Collins, F., 1999. Medical and societal consequences of the Human Genome Project. New England Journal of Medicine, 341, $28-37$.

Collins, F., 2006. The language of God: a scientist presents evidence for belief. New York: Free Press (Simon \& Schuster).

Collins, F. and Galas, D., 1993. A new five-year plan for the U.S. Human Genome Project. Science, 262, $43-$ 46.

Collins, F., et al., 1998. New goals for the U.S. Human Genome Project: 1998-2003. Science, 282, 682689.

Collins, F., et al., 2003. A vision for the future of genomics research, a blueprint for the genomics era. Nature, $422,835-847$.

Cook-Deegan, R., 1994/1995. The gene wars: science, politics and the human genome. New York/London: Norton.

Crick, F., 1988. What mad pursuit: a personal view of scientific discovery. New York: Basic Books.

Davies, K., 2001/2002. Cracking the genome: inside the race to unlock human DNA. Baltimore and London: John Hopkins University Press.

Foucault, M., 1976. Histoire de la sexualité 1: la volonté du savoir. Paris: Gallimard.

Foucault, M. 1984. Histoire de la sexualité 2: l'usage des plaisirs. Paris: Gallimard.

Gilbert, N. and Mulkay, M., 1984. Opening Pandora's Box: a sociological analysis of scientists' discourse. Cambridge: Cambridge University Press.

Gilbert, W., 1991. Towards a paradigm shift in biology. Nature, 349, 99. 
Gratzer, W., 2000. Introduction. In: J. Watson, A passion for DNA: genes, genomes and society. Cold Spring Harbor: Cold Spring Harbor Laboratory Press, xiii-xx.

Hood, L., 2002. My life and adventures integrating biology and technology. A Commemorative Lecture for the 2002 Kyoto Prize in Advanced Technologies [online]. Available from: http://www.systemsbiology. org/download/2002Kyoto.pdf [Accessed October 2008].

IHGSC (International Human Genome Sequencing Consortium), 2001. Initial sequencing and analysis of the human genome. Nature, 405, 860-921.

IHGSC, 2004. Finishing the euchromatic sequence of the human genome. Nature, 431, 931-945.

Jacob, F., 1987/1988. The statue within: an autobiography. Trans. Franklin Philip. New York: Basic Books.

Judson, H.F., 1979. The eighth day of creation: makers of the revolution in biology. Clearwater: Touchstone Books.

Lambright, W., 2002. Managing "big science": a case study of the Human Genome Project. Syracuse: CEPA.

Latour, B., 1984/1988. The pasteurization of France. Trans. A. Sheridan and J. Law. Cambridge: Harvard University Press.

Lenard, P., 1933. Great men of science [Grosse Naturforscher]. London: G. Bell and sons.

Maddox, B., 2002/2003. Rosalind Franklin: the dark lady of DNA. New York: Harper Collins.

Ostwald, W., 1909. Grosse Männer. Leipzig: Akademische Gesellschaft.

Papineau, D., 2004. Speed-reading the book of life: the inside story of Craig Venter's race to sequence the human genome. New York Times, 15 February 2004, 26.

Sanger, F., 1988. Sequences, sequences and sequences. Annual Review of Biochemistry, 57, 1-28.

Shortland, M. and Yeo, R. (eds.) 1996. Telling lives in science: essays on scientific biography. Cambridge: Cambridge University Press.

Shreeve J., 2004. The genome war: how Craig Venter tries to capture the code of life and save the world. New York: Knopf.

Sulston, J. and Ferry, G., 2002/2003. The common thread: science, politics, ethics and the human genome. London: Bantam/Corgi.

The C. elegans Sequencing Consortium et al. 1998. Genome sequence of the Nematode C. elegans: a platform for investigating biology. Science, 282, 2012-2018.

Venter, J.C., 2007. A life decoded: my genome; my life. New York: Viking/The Penguin Group.

Venter, J.C., et al., 2001. The sequence of the human genome. Science, 291(5507), 1304-1351.

Watson, J. 1965. Molecular biology of the gene. Menlo Park: The Benjamin/Cummings Publishing Company.

Watson, J., 1968/1996. The double helix: a personal account of the discovery of the structure of DNA. New York: Simon \& Schuster.

Watson, J., 2000. A passion for DNA: genes, genomes and society. Cold Spring Harbor: Cold Spring Harbor Laboratory Press.

Watson, J.D. and Crick, F.H.C., 1953. A structure for deoxyribose nucleic acid. Nature, 171, 737-738.

Wilkins, M., 2003. The third man of the double helix: an autobiography. Oxford/New York: Oxford University Press.

Zwart, H., 2006. The language of God: a scientist presents evidence for belief [Book review]. Genomics, Society \& Policy, 2(3), 136-141.

Zwart, H., 2007. A life decoded: my genome: my life [Book review]. Genomics, Society \& Policy, 3(3), $64-68$. 